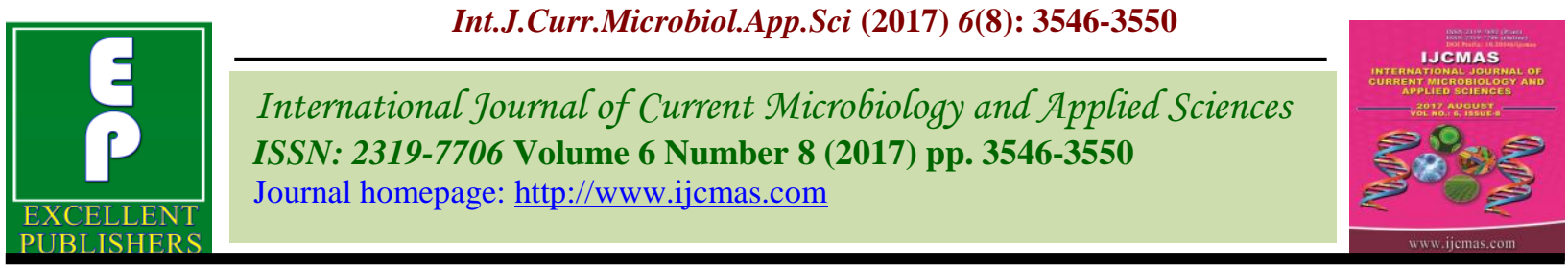

Original Research Article

https://doi.org/10.20546/ijcmas.2017.608.424

\title{
A Change in Economic Level of Cotton Growers under BCI (Better Cotton Initiative) Programme
}

\author{
S. Pallavi*, I. Sreenivasa Rao, N. Venkateshwar Rao, \\ V. Sudha Rani and K.B. Suneetha Devi
}

\begin{abstract}
Department of Agricultural Extension, College of Agriculture, Professor Jayashanakar Telangana State Agricultural University, Rajendranagar, Hyderabad - 500 030, Telangana, India

*Corresponding author
\end{abstract}

\begin{tabular}{|c|}
\hline Keywords \\
\hline $\begin{array}{l}\text { Economic, BCI } \\
\text { (Better Cotton } \\
\text { Initiative), Cotton. }\end{array}$ \\
\hline Article Info \\
\hline $\begin{array}{l}\text { Accepted: } \\
\text { 27 June } 2017 \\
\text { Available Online: } \\
\text { 10 August } 2017\end{array}$ \\
\hline
\end{tabular}

Keywords

Economic, BCI

(Better Cotton Initiative), Cotton.

\section{A B S T R A C T}

The present study was conducted at Karimnagar district of Telangana state and it mainly focuses on "A change in the economic level of cotton growers under BCI programme". A sample of 100 farmers (Beneficiaries 50 and non-beneficiaries 50) was selected for the study. In order to find out the change in the economic level of cotton growers - cost of cultivation, yields, market value and net returns were studied starting from the year of implementation of BCI i.e., from 2012-13 to 2015-16 both for beneficiaries and non-beneficiaries. Based on the results each year, the statistical test i.e. ' $Z$ ' test was applied to find out the difference between the beneficiaries and non-beneficiaries and to know the impact of BCI in each year. From the study it was revealed that significant difference was observed between beneficiaries and non-beneficiaries with respect to reduction in cost of cultivation during the years 2013-14(7.10), 2014-15 (11.25) and 2015-16 (14.03), increase in yields during the years 2013-14 (4.35), 2014-15 (10.58), and 2015-16 (15.18), difference in market value during the years 2013-14 (2.65), 2014-15 (3.72), and 2015-16 (6.74) and increase in net returns during the years 2013-14 (13.76), 2014-15 (10.23), and 2015-16 (17.64).

\section{Introduction}

Cotton, the white gold, being the most important cash crop, is the back bone of cotton farmers of Karimnagar district of Telangana state. With the introduction of Btcotton during the year 2002, there was a decline in pesticide usage. Though pink bollworm damage declined, the changes in pest management systems with reduction in pesticides and introduction of several new $\mathrm{Bt}$ hybrids, most of which were highly susceptible to insect pests and diseases, has resulted in increased damage by sucking pests such as jassids, white flies, thrips, mealy bugs and mired bugs. As a consequence of this, insecticide usage which had declined from Rs.10520 million in 2001 to Rs.5790 million in 2006, increased gradually to Rs.8804 million by 2010 (Central Institute for Cotton Research (CICR) Vision, 2030).

Ever since the introduction of $\mathrm{Bt}$ cotton in India, there were numerous studies on $\mathrm{Bt}$ cotton focused on increase in the productivity, reduction in the insecticide application, good 
return to farm level etc. The focus on high yield production, without taking agriculture and environmental sustainability into account, has become standard practice. Some production practices like wide plant to plant and row to row spacing and crop traits such as indeterminate growth habit, long duration, render the crop susceptible to a multitude of insect pests and diseases at all stages of growth.

These factors are also responsible for high input use in terms of nutrients and crop protection chemicals. The excessive input use not only escalates cost of cultivation, but also decreases profitability and results in pest resurgence, health and environmental hazards. Addressing to the various issues, in 2005 a group of visionary organisations came together to figure out what could be done to safeguard the future of cotton and cotton farmers and they started Better Cotton Initiative (BCI) programme.

Better Cotton Initiative (BCI) is a voluntary programme launched in 2005. The purpose of BCI is to promote strong supply chain linkages with measurable improvements in productivity and reduction in costs of cultivation without adversely affecting the environmental and social impacts. The learning groups were empowered through Farmer Field Schools to reduce harmful impact of use of chemicals, banned pesticides and to promote water conservation, soil health management, protection of natural habitat and management of fiber quality.

\section{Materials and Methods}

The Telangana state was selected purposively for the study. The Karimnagar district of Telangana state was selected as BCI programme has been implemented only in Warangal and Karimnagar Districts. Among these two districts, Karimnagar district was purposively selected for the study because NGO based KVK at Jammikunta has taken lead in implementing the BCI programme.

There are fifty seven (57) mandals in Karimnagar district, among these nine mandals (09) were under BCI programme and out of these nine mandals, five (05) mandals were selected randomly for the study. From each mandal five (05) villages i.e. a total of ten (10) villages were selected randomly. From each selected village, five BCI beneficiary and five non-BCI beneficiary (respondents) were selected randomly, thus a total of 50 beneficiary and 50non beneficiary cotton cultivating farmers were constituted as sample for the study.

In order to find out the change in the economic level of cotton growers - cost of cultivation, yields, market value and net returns were studied starting from the year of implementation of BCI i.e., from 2012-13 to 2015-16 both for beneficiaries and nonbeneficiaries. The data from the respondent farmers were collected with the help of schedules and interviews. The data collected were analysed and suitable interpretations were drawn. The statistical techniques like arithmetic mean, standard deviation and ' $Z$ ' test were followed to analyse the data.

\section{Results and Discussion}

The data were collected from the beneficiaries and non-beneficiaries were analysed and interpreted.

\section{Reduction in cost of cultivation}

The Better Cotton Initiative programme is being implemented in Karimnagar district of Telangana state since 2012-13.From then it was observed that there was a reduction in cost of cultivation among the BCI beneficiaries. 
Cost of cultivation of beneficiaries and nonbeneficiaries has been recorded starting from the year 2012-13 to 2015-2016. The year wise mean cost of cultivation, S.D values and $Z$ values of beneficiaries and non-beneficiaries were calculated and $\mathrm{Z}$ values were also calculated for each year.

It was evident from above table1 that initially i.e., during the year 2012-13 the calculated " $Z$ " value (1.44) was less than the table value. Hence, it can be concluded that there was no significant difference between the beneficiaries and non-beneficiaries during the year 2012-13.

But later years there was a gradual decrease in mean cost of cultivation per acre and increase in the " $Z$ " values i.e., during the years (2013$14,2014-15,2015-16$ ) the corresponding " $z$ " values were $7.10,11.25$, and 14.03 respectively.

Which were greater than the table value which implies that there exists a significance difference between the beneficiaries and nonbeneficiaries with respect to the reduction in cost of cultivation, which shown an impact of BCI in reducing the cost of cultivation (Lakshmi and Rao, 2004).

This is due to beneficiaries have adopted the package of practices which reduced their cost of cultivation, soil test based fertilizer application, installation of yellow sticky traps, intercropping with the pulses, spraying of botanical pesticide and stem application which reduced the expenditures on fertilizers and pesticides.

\section{Increase in yields}

It was evident from above Table 2 that initially i.e., during the year 2012-13 the calculated " $Z$ " value $(0.25)$ was less than the table value. Hence, it can be concluded that there was no significant difference between the beneficiaries and non-beneficiaries during the year 2012-13.

But later years there was a gradual increase in the " $Z$ " values i.e., during the years (2013-14, 2014-15, 2015-16) the corresponding " $z$ " values were $(4.35,10.58,15.18)$ which are greater than the table value which implies that there exists a significant difference between the beneficiaries and non-beneficiaries with respect increase in yields.

It was due to the fact that beneficiaries adopted certain practices under BCI programme which improved the yield were recommended spacing, drip irrigation system at critical stages, application of tank silt, incorporation of cotton stubbles, spraying of potassium nitrate etc (Reddy et al., 2008).

In case of non-beneficiaries it was found that they partially and not adopted most of the recommended practices. The nonbeneficiaries followed the practices with their past experience and they have less interest in adopting latest and new technologies. Due to excess use of fertilizers and chemicals by the non-beneficiaries lead to decrease in the soil fertility and thus reduced the yields.

\section{Difference in market value}

It was evident from above Table 3 that initially i.e., during the year 2012-13 the calculated " $Z$ " value (1.75) was less than the table value. Hence, it can be concluded that there was no significant difference between the beneficiaries and non-beneficiaries during the year 2012-13.It was evident from above Table 4.15 there was a gradual increase in the "Z" values i.e., during the years (2013-14, 2014-15, 2015-16) the corresponding " $z$ " values were $(2.65,3.72,6.74)$ which are greater than the table value which implies that there exists a significant difference between the beneficiaries and non-beneficiaries with respect market value. 
Table.1 Difference between beneficiaries and non-beneficiaries about the difference in cost of cultivation of cotton

\begin{tabular}{|c|c|c|c|c|c|c|}
\hline \multirow[b]{2}{*}{ S. No } & \multirow[b]{2}{*}{ Year } & \multicolumn{2}{|c|}{$\begin{array}{c}\text { Beneficiaries } \\
\quad(n=50)\end{array}$} & \multicolumn{2}{|c|}{ Non-Beneficiaries $(n=50)$} & \multirow[b]{2}{*}{ 'Z' value } \\
\hline & & $\begin{array}{c}\text { Mean cost of } \\
\text { cultivation } \\
\text { Rs/acre }\end{array}$ & S.D & $\begin{array}{c}\text { Mean cost of } \\
\text { cultivation } \\
\text { Rs/acre }\end{array}$ & S.D & \\
\hline 1) & $2012-13$ & 22,940 & 1.43 & 23,300 & 1.02 & 1.44 \\
\hline 2) & 2013-14 & 21,740 & 1.58 & 23,400 & 0.49 & $7.10 *$ \\
\hline 3) & $2014-15$ & 20,840 & 1.73 & 23,900 & 0.84 & $11.25 *$ \\
\hline 4) & $2015-16$ & 20,360 & 1.84 & 24,200 & 0.61 & $14.03 *$ \\
\hline
\end{tabular}

*Significance at 0.05 per cent probability level

Table.2 Difference between beneficiaries and non-beneficiaries about the difference in yields

\begin{tabular}{|c|c|c|c|c|c|c|}
\hline \multirow[t]{2}{*}{ S. No } & \multirow[t]{2}{*}{ Year } & \multicolumn{2}{|c|}{$\begin{array}{c}\text { Beneficiaries } \\
(n=50)\end{array}$} & \multicolumn{2}{|c|}{$\begin{array}{c}\text { Non Beneficiaries } \\
(\mathbf{n}=\mathbf{5 0})\end{array}$} & \multirow[b]{2}{*}{ 'Z' value } \\
\hline & & $\begin{array}{c}\text { Mean yield } \\
\text { (quintal/acre) }\end{array}$ & S.D & $\begin{array}{c}\text { Mean yield } \\
\text { (quintal/acre) }\end{array}$ & S.D & \\
\hline 1) & $2012-13$ & 10.66 & 4.18 & 10.58 & 1.06 & 0.25 \\
\hline 2) & 2013-14 & 11.74 & 1.41 & 10.74 & 0.83 & $4.35^{*}$ \\
\hline 3) & 2014-15 & 12.48 & 1.25 & 10.68 & 0.89 & 10.58 \\
\hline 4) & $2015-16$ & 13.86 & 1.21 & 10.52 & 0.91 & $15.18 *$ \\
\hline
\end{tabular}

*Significance at 0.05 per cent probability level

Table.3 Difference between beneficiaries and non-beneficiaries about the difference in market value

\begin{tabular}{|c|c|c|c|c|c|c|}
\hline \multirow[b]{2}{*}{ S. No } & \multirow[b]{2}{*}{ Year } & \multicolumn{2}{|c|}{$\begin{array}{c}\text { Beneficiaries } \\
\quad(\mathbf{n}=\mathbf{5 0})\end{array}$} & \multicolumn{2}{|c|}{ Non Beneficiaries $(\mathrm{n}=50)$} & \multirow[b]{2}{*}{ ' $Z$ ' value } \\
\hline & & $\begin{array}{c}\text { Market value } \\
\text { (Rs/q) }\end{array}$ & S.D & $\begin{array}{c}\text { Market value } \\
(\text { Rs/q) }\end{array}$ & S.D & \\
\hline 1) & 2012-13 & 3440 & 399.49 & 3330 & 191.92 & 1.75 \\
\hline 2) & 2013-14 & 3490 & 437.71 & 3310 & 199.23 & $2.65^{*}$ \\
\hline 3) & $2014-15$ & 3638 & 440.26 & 3380 & 216.71 & $3.72 *$ \\
\hline 4) & $2015-16$ & 3802 & 421.63 & 3364 & 182.55 & $6.74 *$ \\
\hline
\end{tabular}

*Significance at 0.05 per cent probability level

Table.4 Difference between beneficiaries and non-beneficiaries about the difference in net returns

\begin{tabular}{|l|l|l|l|l|l|l|}
\hline \multirow{2}{*}{ S. No } & \multirow{2}{*}{ Year } & \multicolumn{2}{|c|}{$\begin{array}{c}\text { Beneficiaries } \\
(\mathbf{n = 5 0 )}\end{array}$} & \multicolumn{2}{c|}{ Non Beneficiaries (n=50) } & \multirow{2}{*}{ ' $Z$ ' value } \\
\cline { 3 - 6 } & & $\begin{array}{c}\text { net returns } \\
(\text { Rs/acre) }\end{array}$ & S.D & $\begin{array}{c}\text { net returns } \\
\text { (Rs/acre) }\end{array}$ & S.D & \\
\hline 1$)$ & $2012-13$ & 13430 & 8455.44 & 11930 & 4269.60 & 1.12 \\
\hline 2$)$ & $2013-14$ & 19208 & 7580.45 & 12116 & 3187.11 & $13.76^{*}$ \\
\hline 3$)$ & $2014-15$ & 24490 & 7575.32 & 12214 & 3809.12 & $10.23^{*}$ \\
\hline 4$)$ & $2015-16$ & 32314 & 7963.56 & 11136 & 2931.65 & $17.64^{*}$ \\
\hline
\end{tabular}

*Significance at 0.05 per cent probability level 
It was due to the reason that the quality of the cotton cultivated by the beneficiaries was high when compared to the non-beneficiaries. In case of non-beneficiaries they have not followed the recommended dose and applied excess fertilizers and chemicals as a result their soil productivity was affected and their yields were reduced.

The reason for better market value for the produce of beneficiaries was due to better quality of produce and might be received the market information from the extension functionaries in time because of their better contact compared to non-beneficiaries.

\section{Increase in net returns}

It was evident from the above Table 4 that initially i.e., during the year 2012-13 the calculated " $Z$ " value (1.12) was less than the table value. Hence, it can be concluded that there was no significant difference between the beneficiaries and non-beneficiaries during the year 2012-13.

It was evident from the above Table 4 there was a gradual increase in the " $Z$ " values i.e., during the years $(2013-14,2014-15,2015-16)$ the corresponding " $Z$ " values were $(13.76,10.23,17.64)$ which are greater than the table value which implies that there exists a significant difference between the beneficiaries and non-beneficiaries with respect net returns. Reduction in cost of cultivation, increased yields and market value led to high net returns (Lakshmi and Rao, 2004) and (Kishore et al., 2009).

From the study it can be concluded that significant difference was observed between beneficiaries and non-beneficiaries with respect to reduced cost of cultivation, increased yields, market value and increased net returns during the years 2013-14, 2014-15 and 2015-16. Farmers participating in the programme i.e., beneficiaries had higher yields than nonbeneficiaries and were able to reduce the input costs specially due to reduction in use of Fertilizers, and pesticides (Khan et al., 2004), because of the good quality of fibre it has got good market value there by able to get net additional income (Gahukar, 2008) and thus improving the economic level of cotton growers.

\section{References}

Central Institute for Cotton Research Vision. 2030.1-56. (http://www.cicr.org.in).

Gahukar, R.T., 2008. Experience of collective farming for Cotton production in Vidarbha (Maharashtra). Journal of Cotton Research and Development. 23 (1): 171-174.

Khan, M.A., Ahmad, I and Soomro, M.H. 2004. Impact of IPM based plant protection practices on Biodiversity and Biosafety: evidence from Pakistan. Paper presented in Regional Workshop on IPM-FFS Impacts Analysis, organized by FAO-EU IPM Programme for Cotton in Asia, FAO Regional Office for Asia and Pacific, 39 PhraAtit road, Bangkok, Thailand. 18pp.

Lakshmi, N.V., and Krishna Rao, G.V. 2004. Economics of IPM and non IPM Technologies on cotton and paddy. The Andhra Agricultural Journal. 40 (1\&2): 226-229.

Reddy, G.K., Chabdrashekarreddy, $\mathrm{M}$ and Bali reddy, V. 2008. Economic analysis of cotton production using integrated pest management technologies in Andhra Pradesh. The Andhra Agricultural Journal. 50 (3 \& 4): 393-396.

\section{How to cite this article:}

Pallavi, S., I. Sreenivasa Rao, N. Venkateshwar Rao, V. Sudha Rani and Suneetha Devi, K.B. 2017. A Change in Economic Level of Cotton Growers under BCI (Better Cotton Initiative) Programme. Int.J.Curr.Microbiol.App.Sci. 6(8): 3546-3550. doi: https://doi.org/10.20546/ijcmas.2017.608.424 